\title{
Aplikasi Otentikasi Citra Digital Dengan Metode Adaptive Data Hiding
}

\author{
Damarlin Zalukhu \\ STMIK Budi Darma Medan, JI. Sisimangaraja No.338 Simpang Limun Medan \\ http : //www.stmik-budidarma.ac.id // Email : Damarzal@yahoo.com
}

\begin{abstract}
ABSTRAK
Problems that often occur in internet services make data security not guaranteed. To provide content authentication and duplicate protection from digital data, two complementary techniques have been developed, namely encryption and watermarks. Encryption techniques are used to secure digital data during transmission from sender to receiver. Because digital images can be easily reproduced, cryptosystems cannot solve this problem perfectly. The second security measure that completes encryption is to attach a secret signal, a watermark, directly to the original data so that it remains available during use. Watermarking cannot prevent duplication, modification and distribution of digital media by itself, so it must be combined with cryptography. Embedding is done by modifying the average pixel intensity value of each block in the range determined by the contrast value for a particular block. This reduces the effect of modification as felt by the human eye. The extraction procedure calculates and compares the number of pixel values for blocks of the original image and watermark. The results show the robustness of the scheme towards general image processing operations such as cropping, modification, low pass filters, median pass filters, minimized and lossy JPEG compression with various quality index factors. The results also illustrate that the watermark is safe, restored and recognized even after the watermark image has been damaged, forged and modified by a general image processing operation. A comparative study of the scheme proposed with the existing scheme has also been carried out to observe the strength of the scheme.
\end{abstract}

\section{Kata kunci : Adaptive Data Hiding (ADH), Joint Photographic Expert Group (JPEG), Message Digest (MD), satu arah Hash, Spasial Domain.}

\section{PENDAHULUAN}

Banyak vendor dan pengembang komersial menggunakan internet untuk mengirimkan data dan melakukan transaksi bisnis. Selama transmisi dari data digital, layanan seperti permintaan video, pertukaran data elektronik dan online shopping menghadapi dua permasalahan. Permasalahan pertama adalah bahwa layanan ini rentan terhadap akses yang mudah dari pengguna ilegal sehingga sekuritas data menjadi tidak aman. Permasalahan lainnya adalah layanan ini mudah untuk diduplikasi dan didistribusikan ulang. Untuk menyediakan otentikasi isi dan proteksi duplikasi dari data digital, dua teknik yang saling melengkapi telah dikembangkan, yaitu enkripsi dan watermark [7]. Teknik enkripsi digunakan untuk mengamankan data digital selama transmisi dari pengirim ke penerima.

Skema Adaptive Data Hiding (ADH) ini akan menyembunyikan sebuah citra watermark hitam putih dalam citra asli sehingga menghasilkan sebuah citra watermark baru yang secara kasat mata kelihatan sama dengan citra asli ${ }^{[4]}$. Data yang akan ditempelkan pada citra asli tergantung pada kunci yang dimasukkan, karena citra watermark yang akan ditempelkan pada citra asli akan diproses dengan menggunakan nilai hash dari kunci input. Joint Photographic Experts Group (JPEG) adalah standar citra digital yang digunakan secara luas pada World Wide Web karena rasio citra digitalnya bagus dan kualitas juga.

Skema ini disebut adaptif karena watermark yang dihasilkan adalah aman, dapat diperoleh dan dikenali kembali, sekalipun citra watermark tersebut telah dimodifikasi dengan menggunakan operasi pengolahan citra yang umum digunakan. Skema ini menitikberatkan pada proteksi copyright, otentikasi isi, sekuritas dan robustness. Otentikasi isi dan proteksi copyright dengan sifat robustness dari citra digital tidak bergerak dapat dicapai dengan menggunakan sifat watermarking pada domain spasial sedangkan sekuritas dari skema dapat dicapai dengan menggunakan fungsi kriptografi hash satu arah. 
Berdasarkan uraian latar belakang di atas, maka yang menjadi permasalahan adalah:
1. Bagaiman
teknik
dalam mengotentikasikan citra digital?
2. Bagaimana menerapkan metode Adaptive Data Hiding untuk mengotentikasikan suatu citra digital?

3. Bagaimana merancang aplikasi otentikasi citra digital?

Masalah yang akan dibahas dalam penelitian ini mencakup:

1. Input program adalah citra dalam format BMP dan JPEG.

2. Format citra hasil output sesuai dengan format citra input.

3. Ukuran citra asli yang dapat diproses dengan batasan minimal $100 \times 100$ piksel dan maksimal 1000 x 1000 piksel.

4. Citra asli berupa citra grayscale dan citra watermark berupa citra hitam putih. Citra asli berupa citra berwarna akan dikonversi menjadi citra grayscale.

5. Data kunci input bertipe data string dengan panjang maksimum 8 karakter.

6. Fungsi hash yang digunakan adalah fungsi SHA-1.

\section{LANDASAN TEORI}

\subsection{Otentikasi}

Otentikasi (authentication) merupakan sebuah metode untuk menyediakan jaminan bahwa informasi tidak dimanipulasi oleh pihak yang tidak mempunyai wewenang [1]. Otentikasi bersifat spesifik dalam topik keamanan yang berusaha dicapai. Contohnya meliputi pengendalian akses, otentikasi entity, otentikasi pesan, integritas data, nonrepudiation, dan otentikasi kunci.

\subsection{Fungsi Hash}

Sebuah nilai hash dihasilkan oleh fungsi $\mathrm{H}$ dengan bentuk :

$$
h=H(M) \ldots(1)
$$

dimana $M$ adalah pesan dengan panjang bebas, dan $\mathrm{H}(\mathrm{M})$ atau $\mathrm{h}$ adalah nilai hash dengan panjang tetap ${ }^{[1]}$. Nilai hash ini akan ditambahkan di awal pesan dan kemudian dikirimkan bersamaan. Penerima dari pesan itu akan melakukan otentikasi terhadap pesan itu dengan mengkomputasi nilai hash dan kemudian membandingkannya dengan nilai hash yang ada di awal pesan.

Agar fungsi hash bisa bertindak sebagai otentikasi pesan, fungsi hash $\mathrm{H}$ harus memenuhi syarat - syarat di bawah ini (Stalling, 1995) :

1. H dapat diterapkan pada blok data dengan ukuran berapa pun.
2. $\mathrm{H}$ menghasilkan keluaran dengan panjang yang tetap.

3. Relatif mudah untuk mengkomputasi $\mathrm{H}(\mathrm{x})$ untuk sembarang $x$.

4. Dengan mengetahui nilai hash y, tidaklah bisa secara komputasi untuk menemukan $x$ yang memenuhi $\mathrm{H}(\mathrm{x})=\mathrm{y}$.

5. Dengan mengetahui $x$, tidaklah bisa secara komputasi untuk menemukan $\mathrm{y} \neq$ $x$ dengan $\mathrm{H}(\mathrm{y})=\mathrm{H}(\mathrm{x})$.

6. Tidak bisa secara komputasi untuk menemukan pasangan $(\mathrm{x}, \mathrm{y})$ yang memenuhi $\mathrm{H}(\mathrm{x})=\mathrm{H}(\mathrm{y})$.

Tiga syarat pertama berfungsi sebagai syarat penerapan praktis dari fungsi hash untuk otentikasi pesan.

Syarat keempat adalah syarat "satuarah" (one-way). Mudah untuk menghasilkan kode nilai hash dengan diberikan sebuah pesan tetapi tidak bisa untuk menghasilkan pesan dengan diberikan kode nilai hash.

Syarat kelima menjamin bahwa dengan diberikan pesan asli tidak akan bisa ditemukan suatu pesan lain dengan nilai hash yang sama dengan nilai hash pesan aslinya. Syarat ini adalah untuk mencegah penipuan jika digunakan kode hash yang terenkripsi. Untuk kasus ini, pihak lawan bisa membaca pesan dan juga menghasilkan kode hash-nya. Tetapi karena pihak lawan tersebut tidak memiliki kunci untuk mendekripsikan kode hash tersebut, maka ia tidak akan bisa mengubah pesan tanpa diketahui. Jika syarat ini tidak dipenuhi maka pihak lawan bisa melakukan hal - hal berikut.

1. Mengintersepsi suatu pesan dengan kode hash terenkripsinya.

2. Menghasilkan kode hash yang tidak terenkripsi dari pesan tersebut.

3. Membuat pesan baru yang lain dengan kode nilai hash yang sama dan kemudian mengirimkannya kembali.

Jika kelima syarat di atas dipenuhi, maka fungsi hash tersebut dinamakan fungsi hash yang lemah. Jika syarat keenam juga dipenuhi, maka fungsi hash itu dianggap fungsi hash yang kuat.

Selain untuk otentikasi pesan, fungsi hash juga dapat diterapkan untuk menghasilkan kunci berbasis passphrase. Cara kerjanya adalah sebagai berikut :

1. Dengan menggunakan fungsi hash dihasilkan nilai hash dari passphrase.

2. Nilai hash dari passphrase dijadikan sebagai kunci untuk melakukan enkripsi / dekripsi.

Nilai fungsi hash merepresentasikan pesan yang lebih pendek dari dokumen dari mana nilai tersebut dihitung, nilai ini sering disebut message digest. Message digest 
dapat dianggap sebagai satu "digital fingerprint" dari dokumen yang lebih panjang. Contoh fungsi hash yang terkenal adalah MD2, MD5, SHA dan HAVAL.

Peranan fungsi hash dalam kriptografi adalah dalam hal pengecekan kondisi terhadap integritas pesan dan tanda tangan digital. Suatu digest dapat dibuat publik tanpa menunjukkan isi dokumen dari mana digest tersebut diturunkan. Hal ini sangat penting dalam digital timestamping dimana dengan menggunakan fungsi hash, seseorang dapat memperoleh dokumen dengan stempel waktu (document timestamped) tanpa menunjukkan isi dari dokumen kepada penyedia layanan timestamping.

\subsection{Citra}

Citra adalah suatu representasi (gambaran), kemiripan, atau imitasi dari suatu objek [2]. Citra sebagai keluaran suatu sistem perekaman data dapat bersifat optik berupa foto, bersifat analog berupa sinyal-sinyal video seperti gambar pada monitor televisi, atau bersifat digital yang dapat langsung disimpan pada suatu media penyimpan.

Pada saat ini citra sudah banyak yang diolah secara digital, karena dengan pengolahan citra secara digital citra akan mudah dimanipulasi, misalnya merubah warna, merubah ukuran merubah kecerahan warna ataupun yang lainnya. Salah satu cara untuk memanipulasi citra adalah dengan melakukan transformasi wavelet.

\subsection{Citra Digital}

Citra sebagai keluaran suatu sistem perekaman data dapat bersifat optik berupa foto, bersifat analog berupa sinyal-sinyal video seperti gambar pada monitor televisi, atau bersifat digital yang dapat langsung disimpan pada pita magnetik ${ }^{[2]}$. Menurut presisi yang digunakan untuk menyatakan titik-titik koordinat pada domain spasial atau bidang dan untuk menyatakan nilai keabuaan atau warna suatu citra, maka secara teoritis citra dapat dikelompokkan menjadi empat kelas citra, yaitu citra kontinu-kontinu, kontinu-diskrit, diskrit-kontinu, dan diskritdiskrit, di mana label pertama menyatakan presisi dari titik-titik koordinat pada bidang citra sedangkan label kedua menyatakan presisi nilai keabuan atau warna. Kontinu dinyatakan dengan presisi angka tak terhingga, sedangkan diskrit dinyatakan dengan presisi angka terhingga

\subsection{Watermarking}

Sesuai dengan penjelasan dalam buku Rinaldi Munir 2006,309 yaitu ada beberapa definisi dari watermarking, antara lain watermarking berarti suatu konsep untuk menyisipkan suatu data atau pola ke dalam dokumen sehingga suatu potongan informasi seperti kepemilikan atau identitas konsumen yang berhak untuk menggunakannya berada dalam data tersebut. Selain itu Watermarking merupakan suatu bentuk dari Steganography (Ilmu yang mempelajari bagaimana menyembunyikan suatu data pada data yang lain), dalam mempelajari teknik-teknik bagaimana penyimpanan suatu data digital ke dalam data host digital yang lain (Istilah host digunakan untuk data/sinyal digital yang ditumpangi.). namun ada perbedaan antara watermarking dan steganografi. Jika pada steganografi informasi rahasia disembunyikan di dalam media digital dimana media penampung tidak berarti apa-apa, maka pada watermarking justru media digital tersebut yang akan dilindungi kepemilikannya dengan pemberian suatu informasi tertentu didalamnya.

\subsection{Adaptive Data Hiding untuk Otentikasi Citra Digital}

Penyembunyian data sekumpulan besar data secara rapi pada sebuah citra digital tanpa mengakibatkan degradasi yang signifikan, teknik penyembunyian harus beradaptasi pada karakteristik lokal pada sebuah citra ${ }^{[4]}$.

Beberapa ahli menggunakan kriteria global dimana data tersebut disembunyikan, seperti kriteria statistik yang independen dari citra atau kriteria yang cocok dengan citra tertentu. Namun pendekatan ini hanya dapat diterapkan ketika menyembunyikan data berukuran kecil saja.

\section{PEMBAHASAN}

\subsection{Analisa Masalah}

Seiring dengan perkembangan teknologi komputer yang semakin pesat, proses pemberian copyright pada produk digital merupakan suatu permasalahan penting yang harus diselesaikan. Proses pemberian copyright pada citra digital dapat memanfaatkan teknik watermarking.

Teknik watermarking yang bagus mampu menyembunyikan sekumpulan besar data secara rapi pada sebuah citra digital tanpa mengakibatkan degradasi yang signifikan. Untuk itu, teknik penyembunyian harus beradaptasi pada karakteristik lokal pada citra. Namun, kebanyakan metode yang dikemukakan hanya mampu menyimpan data berukuran kecil saja.

\subsection{Analisa Proses Metode Adaptive Data Hiding (ADH)}


Prosedur kerja dari skema Adaptive Data Hiding untuk Otentikasi Citra Digital dapat digambarkan dalam bentuk flowchart diagram seperti berikut:

1. Proses pembuatan watermark

Proses ini memerlukan beberapa data input, seperti citra asli (berupa citra grayscale), citra watermark (berupa citra hitam putih) dan kunci rahasia (berupa teks / string). Proses ini akan menghasilkan sebuah citra watermark

Tabel 1 Pixel dari citra asli

\begin{tabular}{|l|l|l|l|l|l|l|l|l|l|l|l|l|l|l|l|}
\hline 255 & 255 & 255 & 255 & 255 & 255 & 255 & 255 & 255 & 255 & 255 & 255 & 255 & 255 & 255 & 255 \\
\hline 255 & 255 & 255 & 255 & 255 & 255 & 255 & 255 & 255 & 255 & 255 & 255 & 255 & 255 & 255 & 255 \\
\hline 255 & 255 & 255 & 255 & 255 & 255 & 255 & 255 & 255 & 255 & 255 & 255 & 255 & 255 & 255 & 255 \\
\hline 255 & 255 & 255 & 255 & 255 & 255 & 255 & 255 & 255 & 255 & 255 & 255 & 255 & 255 & 255 & 255 \\
\hline 255 & 255 & 255 & 255 & 255 & 255 & 255 & 255 & 255 & 255 & 255 & 255 & 255 & 255 & 255 & 255 \\
\hline 255 & 255 & 255 & 255 & 255 & 255 & 255 & 255 & 255 & 255 & 255 & 255 & 255 & 255 & 255 & 255 \\
\hline 255 & 255 & 255 & 255 & 255 & 255 & 255 & 255 & 255 & 255 & 255 & 255 & 255 & 255 & 255 & 255 \\
\hline 255 & 255 & 255 & 255 & 255 & 255 & 255 & 255 & 255 & 255 & 255 & 255 & 255 & 255 & 255 & 255 \\
\hline 255 & 255 & 255 & 255 & 255 & 255 & 255 & 255 & 255 & 255 & 255 & 255 & 255 & 255 & 255 & 255 \\
\hline 255 & 255 & 255 & 255 & 255 & 255 & 255 & 255 & 255 & 255 & 255 & 255 & 255 & 255 & 255 & 255 \\
\hline 255 & 255 & 255 & 255 & 255 & 255 & 255 & 255 & 255 & 255 & 255 & 255 & 255 & 255 & 255 & 255 \\
\hline 255 & 255 & 255 & 255 & 255 & 255 & 255 & 255 & 255 & 255 & 255 & 255 & 255 & 255 & 255 & 255 \\
\hline 255 & 255 & 255 & 255 & 255 & 255 & 255 & 255 & 255 & 255 & 255 & 255 & 255 & 255 & 255 & 255 \\
\hline 255 & 255 & 255 & 255 & 255 & 255 & 255 & 255 & 255 & 255 & 255 & 255 & 255 & 255 & 255 & 255 \\
\hline 255 & 255 & 255 & 255 & 255 & 255 & 255 & 255 & 255 & 255 & 255 & 255 & 255 & 255 & 255 & 255 \\
\hline 255 & 255 & 255 & 255 & 255 & 255 & 255 & 255 & 255 & 255 & 255 & 255 & 255 & 255 & 255 & 255 \\
\hline
\end{tabular}

Citra Watermark:

\begin{tabular}{|l|l|l|l|}
\hline $\mathbf{1}$ & $\mathbf{1}$ & $\mathbf{1}$ & $\mathbf{1}$ \\
\hline $\mathbf{1}$ & 0 & 0 & 0 \\
\hline $\mathbf{1}$ & 0 & 0 & 0 \\
\hline $\mathbf{1}$ & $\mathbf{1}$ & $\mathbf{1}$ & $\mathbf{1}$ \\
\hline \multicolumn{5}{|c|}{ Kunci = '123'. }
\end{tabular}

Citra Watermark dipecah menjadi:

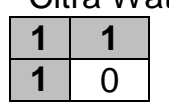

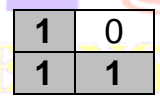

\begin{tabular}{|l|l|}
\hline 0 & 0 \\
\hline 1 & 1 \\
\hline
\end{tabular}

Citra asli dipecah menjadi :

1. High level partition $16 \times 16 / 4 \times 4=4 \times 4$

2. Low level partition $(4 \times 4) \times(2 \times 2)=(8 \times 8)$ \begin{tabular}{|l|l|}
\hline $\mathbf{1}$ & $\mathbf{1}$ \\
\hline 0 & 0 \\
\hline
\end{tabular}

baru yang merupakan citra hasil gabungan dari citra asli dan citra watermark input.

Proses ini memerlukan beberapa input seperti citra asli (citra grayscale), citra watermark hasil dan input kunci. Sedangkan, output dari proses ini adalah citra watermark hitam putih.

Contoh seperti pada tabel berikut: 


\begin{tabular}{|l|l|l|l|l|l|l|l|l|l|l|l|l|l|l|l|}
\hline 255 & 255 & 255 & 255 & 255 & 255 & $\mathbf{2 5 5}$ & $\mathbf{2 5 5}$ & 255 & 255 & 255 & 255 & 255 & 255 & 255 & 255 \\
\hline 255 & 255 & 255 & 255 & 255 & 255 & 255 & 255 & 255 & 255 & 255 & 255 & 255 & 255 & 255 & 255 \\
\hline 255 & 255 & 255 & 255 & 255 & 255 & 255 & 255 & 255 & 255 & 255 & 255 & 255 & 255 & 255 & 255 \\
\hline 255 & 255 & 255 & 255 & 255 & 255 & 255 & 255 & 255 & 255 & 255 & 255 & 255 & 255 & 255 & 255 \\
\hline 255 & 255 & 255 & 255 & 255 & 255 & 255 & 255 & 255 & 255 & 255 & 255 & 255 & 255 & 255 & 255 \\
\hline
\end{tabular}

Hitung nilai :

$\mathrm{H}(123,1,4,4,1,255)=\mathrm{DC} 5 \mathrm{A3C} 3 \mathrm{~B}$

$H(123,2,4,4,2,255)=$ BEA5B411

$H(123,3,4,4,3,255)=F 648 F E 4 E$

$\mathrm{H}(123,4,4,4,4,255)=\mathrm{D} 1 \mathrm{DB} 9 \mathrm{E} 43$

Misalkan diambil bit paling kanan, maka diperoleh:

Kunci untuk subBlok $1=B=1011$

Kunci untuk subBlok $2=1=0001$

Kunci untuk subBlok $3=E=1110$

Kunci untuk subBlok $4=3=0011$

Citra watermark hasil:

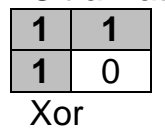

10

11

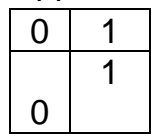

\section{\begin{tabular}{|l|l|}
\hline 1 & 1 \\
\hline 0 & 0 \\
\hline
\end{tabular}}

00

01

\begin{tabular}{|l|l|}
\hline 1 & 1 \\
\hline 0 & 1 \\
\hline
\end{tabular}

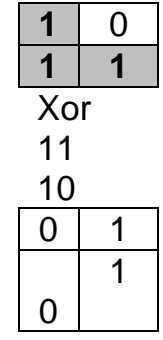

\begin{tabular}{|l|l|}
\hline 0 & 0 \\
\hline 1 & 1 \\
\hline \multicolumn{2}{|l|}{ Xor }
\end{tabular}

00

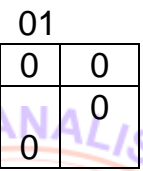

Jadi citra watermark yang akan ditempelkan :

\begin{tabular}{|l|l|l|l|}
\hline 0 & 1 & 1 & 1 \\
\hline 0 & 1 & 0 & 1 \\
\hline 0 & 1 & 0 & 0 \\
\hline 0 & 1 & 0 & 0 \\
\hline
\end{tabular}

Hasil proses penempelan :

Tabel 3 Hasil penempelan citra watermark

\begin{tabular}{|l|l|l|l|l|l|l|l|l|l|l|l|l|l|l|l|}
\hline $\mathbf{2 5 4}$ & 255 & 255 & 255 & 255 & 255 & 255 & 255 & 255 & 255 & 255 & 255 & 255 & 255 & 255 & 255 \\
\hline 255 & 255 & 255 & 255 & 255 & 255 & 255 & 255 & 255 & 255 & 255 & 255 & 255 & 255 & 255 & 255 \\
\hline 255 & 255 & 255 & 255 & 255 & 255 & 255 & 255 & 255 & 255 & 255 & 255 & 255 & 255 & 255 & 255 \\
\hline 255 & 255 & 255 & 255 & 255 & 255 & 255 & 255 & 255 & 255 & 255 & 255 & 255 & 255 & 255 & 255 \\
\hline $\mathbf{2 5 4}$ & 255 & 255 & 255 & 255 & 255 & 255 & 255 & $\mathbf{2 5 4}$ & 255 & 255 & 255 & 255 & 255 & 255 & 255 \\
\hline 255 & 255 & 255 & 255 & 255 & 255 & 255 & 255 & 255 & 255 & 255 & 255 & 255 & 255 & 255 & 255 \\
\hline 255 & 255 & 255 & 255 & 255 & 255 & 255 & 255 & 255 & 255 & 255 & 255 & 255 & 255 & 255 & 255 \\
\hline 255 & 255 & 255 & 255 & 255 & 255 & 255 & 255 & 255 & 255 & 255 & 255 & 255 & 255 & 255 & 255 \\
\hline $\mathbf{2 5 4}$ & 255 & 255 & 255 & 255 & 255 & 255 & 255 & $\mathbf{2 5 4}$ & 255 & 255 & 255 & $\mathbf{2 5 4}$ & 255 & 255 & 255 \\
\hline 255 & 255 & 255 & 255 & 255 & 255 & 255 & 255 & 255 & 255 & 255 & 255 & 255 & 255 & 255 & 255 \\
\hline 255 & 255 & 255 & 255 & 255 & 255 & 255 & 255 & 255 & 255 & 255 & 255 & 255 & 255 & 255 & 255 \\
\hline 255 & 255 & 255 & 255 & 255 & 255 & 255 & 255 & 255 & 255 & 255 & 255 & 255 & 255 & 255 & 255 \\
\hline $\mathbf{2 5 4}$ & 255 & 255 & 255 & 255 & 255 & 255 & 255 & $\mathbf{2 5 4}$ & 255 & 255 & 255 & $\mathbf{2 5 4}$ & 255 & 255 & 255 \\
\hline 255 & 255 & 255 & 255 & 255 & 255 & 255 & 255 & 255 & 255 & 255 & 255 & 255 & 255 & 255 & 255 \\
\hline 255 & 255 & 255 & 255 & 255 & 255 & 255 & 255 & 255 & 255 & 255 & 255 & 255 & 255 & 255 & 255 \\
\hline 255 & 255 & 255 & 255 & 255 & 255 & 255 & 255 & 255 & 255 & 255 & 255 & 255 & 255 & 255 & 255 \\
\hline
\end{tabular}

Proses ekstraksi:

Dari citra watermarking yang diperoleh diatas, dibandingkan dengan citra asli, sehingga diperoleh:

\begin{tabular}{|l|l|l|l|}
\hline 0 & 1 & 1 & 1 \\
\hline & 1 & 0 & 1 \\
\hline
\end{tabular}

\begin{tabular}{|l|l|l|l|}
\hline 0 & & & \\
\hline 0 & 1 & 0 & 0 \\
\hline 0 & 1 & 0 & 0 \\
\hline
\end{tabular}

Hitung nilai :

$\mathrm{H}(123,1,4,4,1,255)=\mathrm{DC} 5 \mathrm{~A} 3 \mathrm{C} 3 \mathrm{~B}$ 
$\mathrm{H}(123,2,4,4,2,255)=\mathrm{BEA5B} 411$

$\mathrm{H}(123,3,4,4,3,255)=$ F648FE4E

$\mathrm{H}(123,4,4,4,4,255)=\mathrm{D} 1 \mathrm{DB} 9 \mathrm{E} 43$

Misalkan diambil bit paling kanan, maka diperoleh:

Kunci untuk subBlok $1=\mathrm{B}=1011$

Kunci untuk subBlok $2=1=0001$

Kunci untuk subBlok $3=\mathrm{E}=1110$

Kunci untuk subBlok $4=3=0011$

XOR kan ulang sehingga diperoleh citra watermark semula.

4. ALGORITMA DAN IMPLEMENTASI

\subsection{Algoritma Dengan Metode Adaptive} Data Hiding (ADH)

Algoritma yang digunakan untuk membuat perangkat lunak dapat dirincikan sebagai berikut:

1. Proses Penempelan

Input

originalArray $\leftarrow \quad$ warna citra asli (citra grayscale)

originalArray1 $\leftarrow$ warna citra hitam putih (citra watermark)

nUkuranX1 $\leftarrow$ nilai $X$ dari ukuran blok

nUkuranY1 $\leftarrow$ nilai $Y$ dari ukuran blok

Output

originalArray $\leftarrow$ warna

watermark hasil

Proses :

Hitung ukuran subblok dari citra watermark.

$\mathrm{nWdt}=$ Original1.Width $\backslash$ nUkuranX1

$\mathrm{nHgt}=$ Original1. Height $\backslash$ nUkuranY1

Hitung nilai mean dari setiap subblok.

nArrMean $=0$

For $\mathrm{u}=1$ sampai jumlah blok For $\mathrm{j}=0$ To nUkuranY1 - 1

For $\mathrm{i}=0$ To nUkuranX1 - 1 $\mathrm{nArrMean}=\mathrm{nArrMean}+$

$\operatorname{Subblok}(u, j, \mathrm{i})$ Next
Next
nArrMean = nArrMean /

(nUkuranX2 * nUkuranY2)

Next

Hitung nilai hash dari setiap subblok

For $\mathrm{u}=1 \mathrm{To} \mathrm{nWdt}$ * $\mathrm{nHgt}$ nMean))

$\mathrm{nArrHash}(\mathrm{u})=\mathrm{SHA}($ Kunci +

Next

Hitung citra hasil dengan melakukan operasi XOR antara nilai hash dari subblok watermark

For $\mathrm{u}=1$ To $\mathrm{nWdt}$ * $\mathrm{nHgt}$

For $\mathrm{j}=0$ To nUkuranY1 - 1

For $\mathrm{i}=0$ To nUkuranX1 - 1
$\operatorname{SubBlokH}(u, j, i)=$

SubBlokWatermark(u, j, i) Xor

nArrHash(u)

\author{
Next \\ Next \\ Next
}

2. Proses Ekstraksi

Input

originalArray $\leftarrow$ warna citra asli (citra grayscale)

originalArray1 $\leftarrow$ warna citra watermark hasil

nUkuranX1 $\leftarrow$ nilai $X$ dari ukuran blok

nUkuranY1 $\leftarrow$ nilai $Y$ dari ukuran blok

Output

originalArray2

$\leftarrow$

warna citra watermark terekstrak

Proses

Ekstrak decoded bit dengan membandingkan nilai mean dari subblok watermark

dan subblok citra asli.

For $\mathrm{j}=1$ To nSubBlokY1

For $\mathrm{i}=1$ To $n$ SubBlokX1

nMean $1=0$

For j1 = 0 To nSubBlokY - 1

For i1 = 0 To nSubBlokX - 1

nMean1 $=$ nMean $1+$

originalArray(j1, i1)

Next

Next

nMean2 $=0$

For $\mathrm{j} 1=0$ To nSubBlokY -1

For i1 $=0$ To nSubBlokX - 1

nMean2 +=

originalArray1(j1, i1)

Next

Next

If nMean2 < nMean1 Then cDecodedBit $(j, i)=0$

$$
\text { Else }
$$

Next

cDecodedBit $(j, i)=1$

Next

Hitung nilai hash dari setiap subblok

For $u=1$ To nWdt * $n \mathrm{Hgt}$ nMean))

$\mathrm{nArHash}(\mathrm{u})=\mathrm{SHA}($ Kunci +

Next

Hitung citra hasil dengan melakukan operasi XOR antara nilai hash dari subblok watermark

For $u=1$ To $n W d t ~ * n H g t$

For $\mathrm{j}=0$ To nUkuranY1 - 1

For $\mathrm{i}=0$ To nUkuranX1 - 1

$\operatorname{SubBlokH}(u, j, i)=$

SubBlokWatermark(u, j, i) Xor

nArrHash(u)

Next 


\section{Next \\ Next}

\subsection{Implementasi}

Untuk menggunakan perangkat lunak ini, jalankan file "Adaptive Data Hiding.EXE", maka akan ditampilkan tampilan utama dari program seperti terlihat pada gambar berikut:

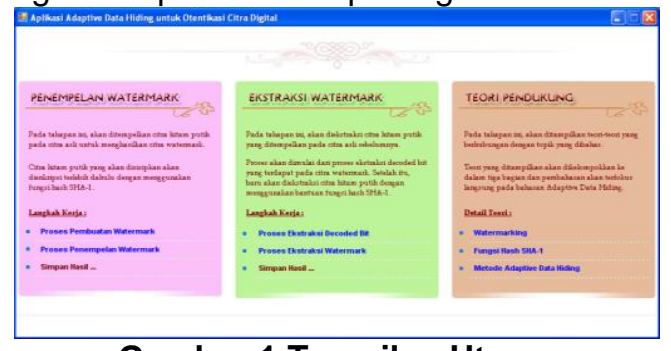

Gambar 1 Tampilan Utama

\section{Proses Pembuatan Watermark}

Untuk melakukan proses pembuatan watermark, maka dapat mengklik link 'Proses Pembuatan Watermark' sehingga sistem akan menampilkan form berikut:

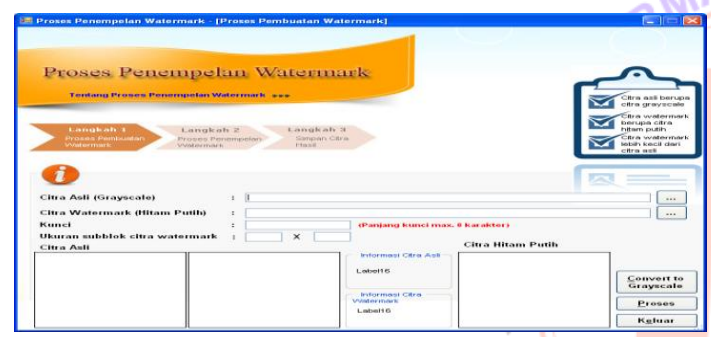

Gambar 2 Tampilan Proses Pembuatan Watermarking Sebelum Mengeksekusi Proses

Pilihlah citra asli dan citra watermark yang ingin diproses. Setelah itu, input data kunci dan ukuran subblok citra watermark. Apabila citra input berupa citra berwarna, maka kliklah tombol 'Convert to Grayscale' untuk mengkonversikan citra asli ke bentuk grayscale.

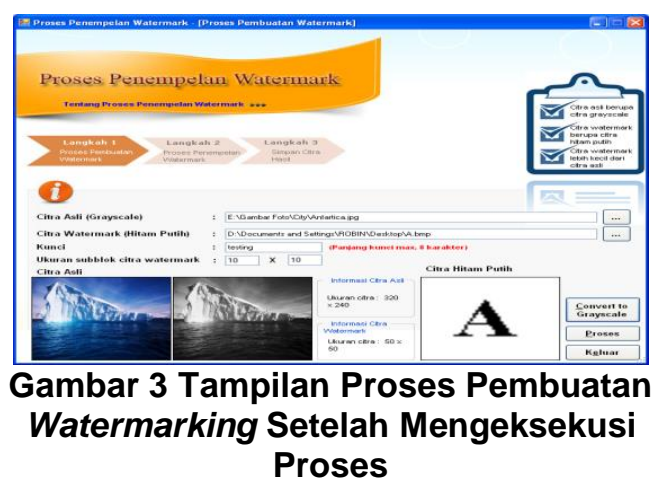

Setelah semua data dimasukkan, kliklah tombol 'Proses' untuk melakukan proses pembuatan watermark dan melanjutkan ke proses selanjutnya yaitu proses penempelan watermark. Sistem akan menampilkan form seperti terlihat pada gambar berikut:

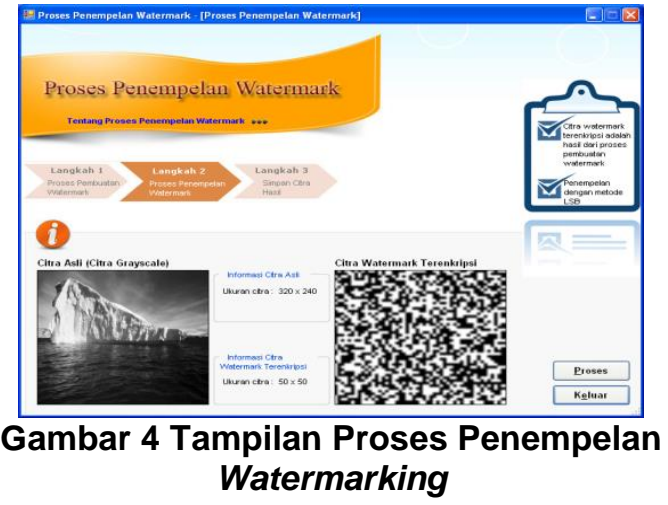

Pada tampilan ini akan ditampilkan citra watermark terenkripsi yang akan disisipkan ke dalam citra asli. Setelah itu, kliklah tombol 'Proses' sehingga sistem akan menampilkan form untuk melakukan proses penempelan watermark terenkripsi ke dalam citra watermark terenkripsi dan melakukan penyimpanan citra hasil watermarking.

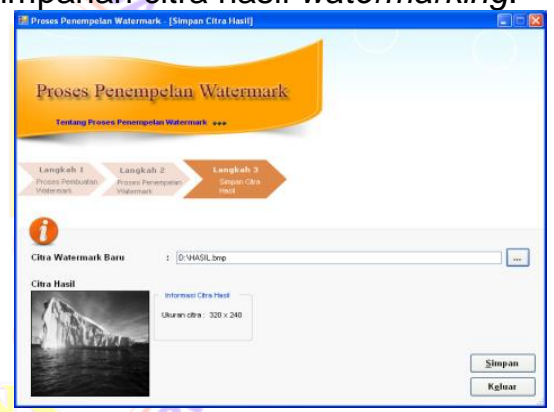

Gambar 5 Tampilan Proses Penyimpanan Citra Hasil Watermark

Proses Ekstraksi Watermark

Untuk melakukan proses pembuatan watermark, maka dapat mengklik link 'Proses Ekstraksi Watermark' sehingga sistem akan menampilkan form berikut:

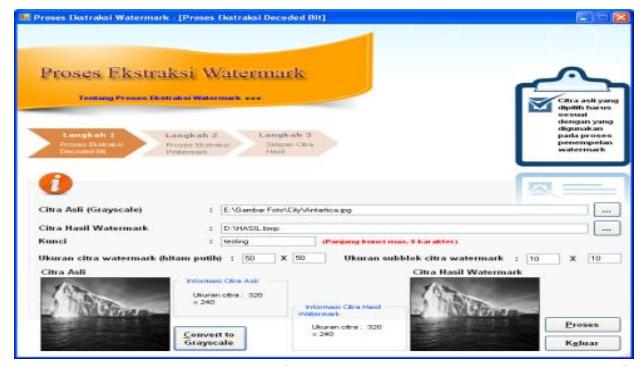

Gambar 6 Tampilan Proses Ekstraksi Watermarking untuk Proses Ekstraksi Decoded Bit

Setelah itu, kliklah tombol 'Proses' sehingga sistem akan menampilkan form 'Ekstraksi Decoded Bit' seperti terlihat pada gambar berikut: 


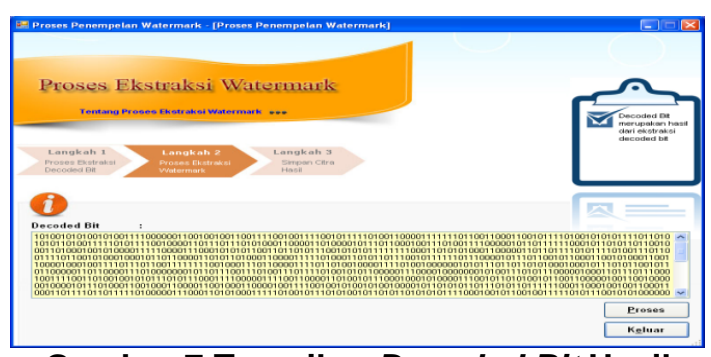

Gambar 7 Tampilan Decoded Bit Hasil Proses Ekstraksi Watermark

Setelah itu, kliklah tombol 'Proses' sehingga sistem akan menampilkan citra watermark yang terekstrak keluar, seperti terlihat pada gambar berikut:

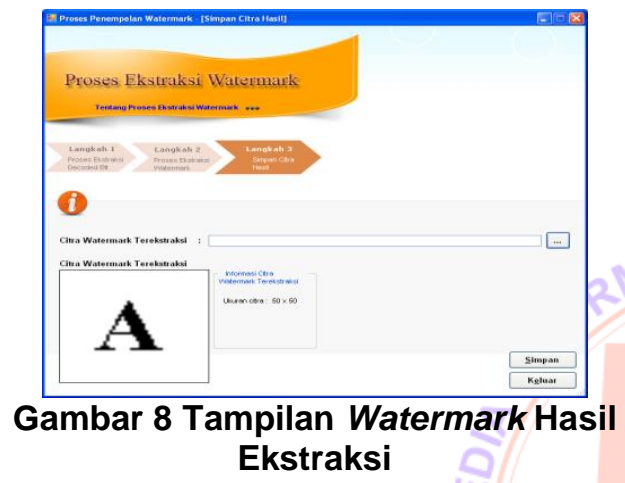

\section{KESIMPULAN}

Setelah menyelesaikan pembuatan perangkat lunak ini, penulis dapat menarik beberapa kesimpulan sebagai berikut:

1. Teknik Otentikasi Citra Digital dengan menggunakan metode Adaptive Data Hiding (ADH) dapat diaplikasikan dengan menggunakan Microsoft Visual Basic 2008.

2. Dimensi citra input dan citra hasil tidak berubah dan perbedaan warna citra input dan citra hasil juga tidak kelihatan jelas.

3. Skema Adaptive Data Hiding untuk Otentikasi Citra Digital mampu mengekstrak keluar citra watermark.

\section{DAFTAR PUSTAKA}

1. Munir. R, 2006, Pengolahan Citra Digital, Bandung, Informatika Bandung

2. Sutoyo.T dkk, 2009, Teori Pengolahan Citra Digital, Yogyakarta, ANDI dan UDINUS

3. Kadir Abdul,2005, Pengenalan Teknologi Sistem Informasi, Yogyakarta, Andi Offset

4. Sarabjeet S. Bedi, Shekhar Verma and Geetam Tomar Member, IEEE, Citra Digital Untuk Metode Adaptive Data Hiding(ADH) 2010,122.

5. Junindar, 2008 Visual Basic 2008
6. Wikipedia, Table ASCIL, <http://www.ascii.cl/htmlcodes.htm>, 08 Juli 2014, 5:46:10

7. (http://wsilfi.staff.gunadarma.ac.id/Down loads/files/1034/Pengenalan+UML.pdf 08 Juli 2014,09:46:10) 